\title{
PROPOSAL FOR THE EVALUATION OF THE STABILITY LEVEL OF PERIODIC TIMETABLE IN TERMS OF OPERATION AND INFRASTRUCTURE
}

\begin{abstract}
The introduction of tact timetable in rail passenger transport is currently a new evolving trend that increases the efficiency of rail transport. This article seeks to contribute in this area of the issue and thus to raise and improve this system of organizing transport in railway transport. The aim is to propose a methodology that assesses the level of stability of tact timetable based on operational and infrastructural factors. The methodology identifies operationalinfrastructural factors that affect the stability and reliability of tact timetable. Using scientific methods, it presents the method of their quantification and determination of the weights of these factors, which evaluate the line sections and transport points of the examined transport path. From a practical point of view, the methodology is generally tact applicable to other European railway networks. In the final part of the work, this methodological procedure is applied in the form of model examples for various transport path.
\end{abstract}

Keywords: Railway transport, Capacity, Periodic timetable, Stability

Lukáš Čechovič ${ }^{1}$

${ }^{I}$ Faculty of Operation and Economics of Transport and Communications; University of Žilina, Univerzitná 8215/1, 01026 Žilina; +421/41/51334 34; lukas.cechovic@fpedas.uniza.sk

Adrián Šperka²

${ }^{2}$ Faculty of Operation and Economics of Transport and Communications; University of Žilina, Univerzitná 8215/1, 01026 Žilina; +421/41 513 3434, adrian.sperka@fpedas.uniza.sk

Jozef Gašparík ${ }^{3}$

${ }^{3}$ Faculty of Operation and Economics of Transport and Communications; University of Žilina, Univerzitná 8215/1, 01026 Žilina; +421/41 513 3406; jozef.gasparik@fpedas.uniza.sk

\section{Introduction}

Today's modern trend in compiling timetables is the introduction of tact or tact timetable. This mode of operation has been researched and tested for several years in other developed countries such as Switzerland and Germany. Scheduling a tact timetable with regular connections to other lines of connecting railway has proven to be one of the successful tools for providing quality transport services and thus to attract and retain public transport users more closely. Such a timetable also has its disadvantages and poses its risks. As it requires high reliability of running times, it is necessary to ensure its stability to maintain its quality.

The daily timetable is a stochastic process, and the occurrence of any unforeseen event can cause delays and their subsequent spread, which can have a negative impact not only on the carrier but also on passengers. This article describes a proposal for a methodological procedure for assessing the stability of tact timetable in terms of operational and infrastructural factors. By researching and finding an effective way in the field of reliability of tact timetables, the authors sought to contribute to the optimization of railway capacity and to broaden the perception of the element of stability from another point of view.

\section{Stability of periodic timetable}

The capacity of the railway network is limited by its bottle necks - elements (track sections and railway junctions), i. e. places whose capacity is used to the maximum and their higher use would endanger the stability of the timetable. The capacity of these constraints cannot be used any more, but professionals need to look for new ways to use existing infrastructure more efficiently.

It follows that it is necessary to thoroughly assess the infrastructure and operational level of the transport path. It is therefore the implementation of the train service plan and the basis of the level of stability which is directly related to the safety of the railway system. The main core of the operational level is the train timetable. It is therefore important to design a highquality timetable.

According to the studies of V. Cacchiani and P. Toth, we can divide the problems of stability of timetables into four areas:

1. synetrical (periodic) or asynmetrical timetables;

2. railway network or single track;

3. freight orpassenger transport;

4. various other objective functions.

We can say that stability is a broad concept. We can also define it as the ability to survive or as a model of balance. It is a caching-capable ability to restore the status of a timetable that acts as a cache. It is important to note that stability is inversely proportional to the capacity of rail transport. Under normal circumstances, the higher the utility capacity ratio, the less time left to compensate for time delays. This "balancing" backup time is therefore in the two components of the timetable. 
The first component is the journey time on the track sections and the second component is the residence time at the railway stations. Optimizing the stability of the timetable is the ability to absorb timetable disruption and adjust the departure and arrival time of trains in the railway station described by Xuelei M.E.

Andersson et al. presented a way to quantitatively measure timetable robustness to identify emerging timetable shortcomings and thus provide a proposal for improvement. The constantly growing demand for railway capacity sometimes leads to high-capacity consumption, resulting in a network sensitive to delays with insufficient robustness. According to this theory, it is important to identify the so-called critical points where trains can increase delays in the delay that has already occurred. Based on this, it is necessary to set the time reserves correctly before and after the critical point. Sufficiently available time spans (accumulated amount of reserve) before the critical point increase the train's ability to arrive on time. On the contrary, the margin of time of the incoming train after the critical point to the next stopping point increases the possibility to delay this train in favor of other trains.

Caimi et al. in the process of tact transport they developed the idea of dividing the railway network into condensation zones (areas with a bottle neck where the smallest possible time reserves and high accuracy are needed due to better capacity utilization) and into compensation zones (places where higher time reserves are needed to compensate for small delays from condensation zones) to solve the problem of timetables. Condensation zones are located near major railway junctions where available capacity is limited and therefore maximum speed is required from trains. On the other hand, train network is less dense in the compensation zones that connect the condensation zones. In this way, time reserves can be introduced for train running in compensation zones in order to increase the stability of the timetable. each zone is then treated according to its specific property.

\section{Proposal of a methodology for evaluating the stability of periodic timetable from an operational- infrastructural point of view}

The proposed methodology is to be used to evaluate the stability of the constructed tact timetable in terms of operational and infrastructure. In other words, it is a more complex indicator of infrastructure-operational conditions, which in a relative relationship expresses the percentage risk of instability of the timetable or its ability to reduce the transmission of delays. The larger the stability indicator, the more stable tact timetable is, which leads to its reliability. Stability assessment is based on the principle of comparing operational and infrastructural factors that affect the stability of tact timetable. An important part of this proposal was the correct setting of the quantification of these assessed factors that assess the stability. The first step is to divide the transport route into interstation sections, which will be separated by transport points where delays can be compensated. These transport points include railway stations and passing point. Another important part of the methodological procedure is the determination of condensation and compensation zones based on the evaluated factors. It is this ratio that helps us determine the level of tact timetable stability.

Condensation zones are very sensitive to time and reliability. These are therefore mainly sections or transport points with a low ability to reduce the transmission of delays. These areas are characterized by short stopping time of a train, slow travel time, operating control point with a small number of running tracks or a low number of block sections, etc.

Compensation zones serve to compensate for the time when the delay is created, i.e., the times of the initial delay. They can also be used to overtaking and train crossing when organizing transport so as to reduce the risk of reduced travel times in condensation zones and thus ensure the reliability of tacts. Thus, these are zones that are the opposite of condensation zones. We can say that these zones serve as areas that provide a "backup time well". Based on this characteristic, this methodology does not pass points as transport points and, due to operational and technological functions, passing points defines it as a compensation zone.

The higher the number of compensation zones, the greater the stability of tact timetable. Due to the difference in operational-infrastructural factors, it is necessary to evaluate interstation sections and transport points separately for even and odd directions due to different stopping time of a train or directional and slope conditions, which affects the travel times of passenger trains. After determining the indicator of stability of interstation sections and transport points, the average value of these two indicators is determined, which expresses the resulting overall stability of tact timetable of the given transport route. For easier understanding, this proposed methodological procedure was processed into individual steps.

Summary of the methodological procedure in partial steps:

Step 1: Dividing the transport route into interstation section and transport points.

Step 2: Identification of operational-infrastructure factors using the documents of the infrastructure manager.

Step 3: Quantification of factors (allocation of weights).

Step 4: The sum of all assigned weights of the interstation section and transport point factors.

Step 5: Determination of condensation and compensation zones.

Step 6: Determine the stability of interstation sections and transport points.

Step 7: Determine the overall tact timetable stability of the examined transport route. 
The complex heuristic procedure for determining the level of stability according to the mentioned partial steps is graphically processed in Figure 1.

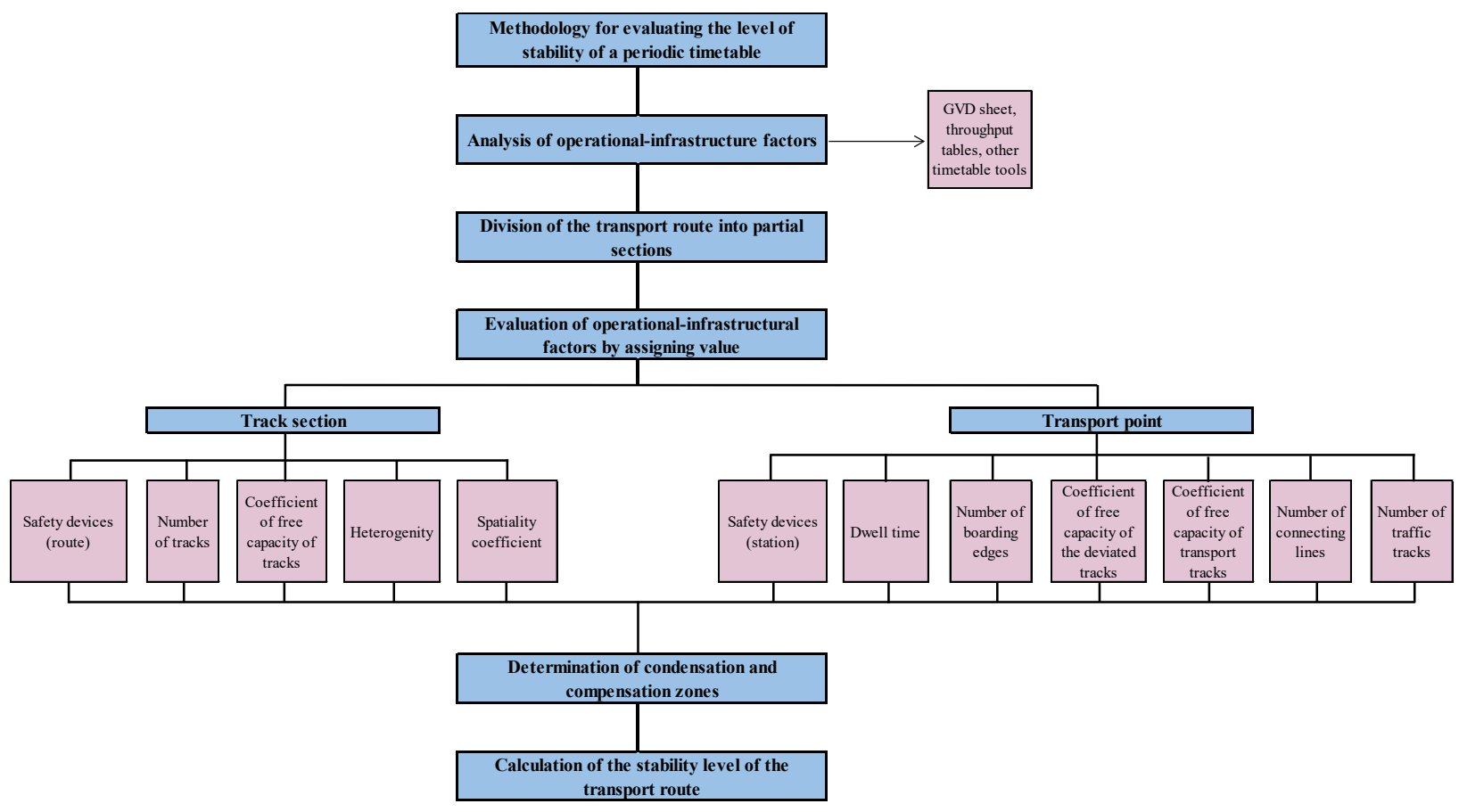

Fig. 1. Graphical representation of the methodical procedure

\section{Characteristic of identified factors}

Stopping time of a train - when quantifying the stopping time of a train for a given transport point, the average value of the stopping time of passenger trains is used:

stopping time of a train $=\frac{\sum t_{p}^{o S}}{N_{v l}}$

where:

$t_{p}{ }^{O S}$ - stopping time of a passenger trains

$\mathrm{Nvl}$ - the number of passenger trains stopping at a given transport point

Spatiality coefficient - this factor in the proposed methodological procedure considers the average travel time in each section of track and the number of open lines. The more open lines there are on the interstation section, the more this interstation section can reduce the delays. We calculate the value of the coefficient as:

$k_{p r}=\frac{n^{P O}}{t_{j}^{T U}}$

where:

$k_{p r}$ - apatiality coefficient

$n^{P O}$ - number of open lines on interstation section

$t_{j}^{T U}$ - average travel time of passenger trains on the interstation section considered
Number of main tracks - this infrastructure factor expresses the number of main tracks on a given interstation section. With a larger number of main tracks, the risk of transmission of delays in the event of unexpected situations by the carrier or the infrastructure manager, such as e.g., exclusions, accidents, technical failure of rail vehicle, etc.

Coefficient of free capacity of main tracks expresses free or usable capacity of the interstation section. It takes into account the practical utilization factor given by the infrastructure manager. From the regulatory point of view, $100 \%$ means maximum capacity utilization, if we subtract the value of practical utilization from this number, we get the value of free capacity:

$k_{v k}^{T K}=1-k_{p}$

where:

$k_{v k}-$ coefficient of free capacity

$k_{p}$ - coefficient of practical use

Heterogeneity - this train traffic diagram factor has a significant effect on tact timetable stability. The use of several types of trains in tact timetable results in different occupation times of the interstation section or travel times or even stopping time of a train which creates inconsistent technological and operational conditions. To methodically quantify this factor, it was 
necessary to assign weights to the individual degrees of heterogeneity, which are shown in Table 1.

Table 1. Determination of the heterogeneity factor using the weight of the criterion.

\begin{tabular}{|c|c|}
\hline \multicolumn{2}{|c|}{ Evaluation of the heterogeneity factor } \\
\hline $\begin{array}{c}\text { Number of types of trains of the } \\
\text { examined transport route }\end{array}$ & Weight \\
\hline 1 species & 6 \\
2 species & 5 \\
3 species & 4 \\
4 species & 3 \\
5 species & 2 \\
6 species & 1 \\
\hline
\end{tabular}

Number of edge of platforms - expresses the number of edges of platform at the transport point. The more edge of platforms there are or the more platforms, the more passenger trains we can put on the boarding and getting out of passengers at a given transport point. This way, the missed train does not have to wait for the running track with the edge of platforms to be released.

Coefficient of free capacity of station gridiron and running tracks - is determined in the same way as the coefficient of free capacity of main tracks.

$k_{v k}^{z h}=1-k_{p}$

$k_{v k}^{d k}=1-k_{p}$

where:

$k_{v k^{z h}}$ - coefficient of free capacity of station gridiron $k_{v k}{ }^{d k}$ - coefficient of free capacity of main tracks

Number of connecting railway - this factor expresses the number of lines leading to the transport point. The more lines connected to a transport point, the more complex the transport management and the number of endangered places increases. This factor is expressed by a negative value of the number of connected lines.

Number of running tracks - is a factor considering the number of running tracks at the transport point. With a larger number of running tracks, transport management is easier, even in the case of overtaking of a train or crossing delayed trains.

Safety installation - expresses the value of safety installation in terms of speed of delay reduction according to individual types of block system and interlocking. This factor was difficult to quantify and for this reason the Saaty multicriteria decision method was used to determine the weight of the criterion, which compared the safety installation according to three variants:

1. delay reduction rate

2. security level

3. station and track operating intervals

The resulting values for determining the weights of safety installation are processed in Table 2.
Table 2. Values for quantification of block system and interlocking

\begin{tabular}{|c|c|}
\hline \multicolumn{2}{|c|}{ Block systems } \\
\hline Type & Weight \\
\hline Automatic block & 0,78 \\
\hline $\begin{array}{c}\text { Automatic signal box with } \\
\text { signal point }\end{array}$ & 0,76 \\
\hline $\begin{array}{c}\text { Automatic signal box } \\
\text { without signal point/semi- } \\
\text { automatic block system }\end{array}$ & 0,67 \\
\hline telephone communication & 0,49 \\
\hline \multicolumn{2}{|c|}{ Interlocking } \\
\hline Type & Weight \\
\hline Electromechanics signal box & 0,63 \\
\hline All-relay interlocking box & 0,60 \\
\hline $\begin{array}{c}\text { Type electric interlocking } \\
\text { devices }\end{array}$ & 0,56 \\
\hline $\begin{array}{c}\text { Electromechanics signal } \\
\text { box/electrodynamic signal } \\
\text { box }\end{array}$ & 0,51 \\
\hline $\begin{array}{c}\text { mechanical interlocking } \\
\text { cabin }\end{array}$ & 0,50 \\
\hline
\end{tabular}

\section{Method for determining the stability of constructed tact timetable}

The next step after assigning weights to the individual criteria, the method of determining, which is described in the previous chapter, is to determine the stability of interstation sections and transport points. The allocation of these transport route weights is based on the infrastructure manager's documents such as train traffic diagram equipment, routing diagram, railway guide, carrying capacity tables, etc. After assigning weights to all factors on each interstation section and at the transport point, all factor weights in the lines must be added, separately for the interstation section and separately for each transport point and subsequently divide these points and sections into condensation and compensation zones. To determine the stability of tact timetable based on operational-infrastructural factors, it is necessary to divide the transport route into condensation and compensation zones. Evaluation of the originating points and terminating points of the transport route where the lines originate, or they disappear is not relevant, because we do not consider these points as places where we can reduce delays but as places where it is necessary for trains to run on time.

These zones can be determined as condensation zones, although we will not include them in the calculations of the evaluation of the stability of the transport route. Also, another exception in this methodological procedure is the turnouts. These specific transport points are mainly used for train crossing and overtaking of a train, thus acting as compensation zones. For this reason, turnouts are fixed as compensation zones as transport points. It is not necessary to assign weights to switches, but in relation (6) we calculate them for the calculation of tact timetable stability. 
Stability level $=\frac{\text { number of compensation zones }}{\text { total number of zones }}$

In order to be able to determine these zones on the basis of individual weight sums, it is necessary to know the break value of the weight sums, ie the value from which larger values including the upward break value will determine the compensation zones and the sum values below this number will determine the condensation zones. We determine this value according to the relation:

Break value when determining zones $=$

the total sum of the weights of the critrria of the evaluated factors total number of rated zones

The last step is to determine the overall stability of the tact timetable transport route based on the evaluation of operational-infrastructure factors. This stability is expressed by the resulting average value of the stability of interstation sections and transport points.

The level of stability of the train path $=$

$\frac{\text { stability of interstation section+stability transport points }}{2}$

The optimal value of the stability level of the transport session recommends accepting the values defined in the UIC 406 regulation concerning the consumption of railway infrastructure capacity. Determining the optimal consumption of railway infrastructure capacity is problematic due to several factors that affect it. The standard values depend on the investigated line, the composition of the bag routes and the specific infrastructure conditions. Nevertheless, UIC 406 stipulates the optimal use of railway infrastructure capacity according to the values defined in Table 3 . We propose that the indicator "level of stability of the transport route" should consider the values determined by UIC 406. We can assume that if, 6 for lines with greater heterogeneity of traffic, we can say that the level of stability of the transport route (8) should also have a value of at least 0.6 .

Table 3. Recommended values of the occupancy time coefficient according to UIC

\begin{tabular}{|l|c|c|}
\hline Type of track & Traffic peak & $\begin{array}{c}\text { All day } \\
\text { long }\end{array}$ \\
\hline $\begin{array}{l}\text { reserved for suburban } \\
\text { service }\end{array}$ & 0,85 & 0,70 \\
\hline high speed tracks & 0,75 & 0,60 \\
\hline $\begin{array}{l}\text { Track with mixed } \\
\text { type of trains }\end{array}$ & 0,75 & 0,60 \\
\hline
\end{tabular}

\section{Application of the proposed methodology}

This chapter deals with the practical results of the applied methodology for a specific transport route Humenné - Košice on the ŽSR network in the even direction.

Table 4. Calculation of spatiality coefficient for even direction Humenné - Košice

\begin{tabular}{|c|c|c|c|}
\hline Interstation section & $\begin{array}{c}\text { Average driving } \\
\text { time on the } \\
\text { interstation section }\end{array}$ & $\begin{array}{c}\text { Number of } \\
\text { open lines }\end{array}$ & Spatiality coefficeint \\
\hline Humenné - Strážske & 31 & 1 & 0,032 \\
\hline Strážske - Petrovce n. Laborcom & 24 & 1 & 0,042 \\
\hline Petrovce n. Laborcom - Michalovce & 14 & 1 & 0,071 \\
\hline Michalovce - Bánovce n. Ondavou & 26 & 1 & 0,038 \\
\hline Bánovce n. Ondavou - Hrinište & 15 & 1 & 0,067 \\
\hline Hrinište - Trebišov & 15 & 1 & 0,067 \\
\hline Trebišov - Čel'ovce & 17 & 1 & 0,059 \\
\hline Čel'ovce - Výh. Slivník & 16 & 1 & 0,063 \\
\hline Výh. Slivník - Slanec & 31 & 6 & 0,194 \\
\hline Slanec - Ruskov & 22 & 5 & 0,227 \\
\hline Ruskov - Nižná Mšl'a & 21 & 5 & 0,238 \\
\hline Nižná Myšl’a - Krásna n. Hornádom & 22 & 5 & 0,227 \\
\hline Krásna n. Hornádom - Košice & 30 & 5 & 0,167 \\
\hline
\end{tabular}


Table 5. Allocation of weights by factors of line sections of the Humenné - Košice transport route

\begin{tabular}{|c|c|c|c|c|c|}
\hline \multirow[b]{2}{*}{$\begin{array}{c}\text { Name of operating control } \\
\text { point/open line }\end{array}$} & \multicolumn{5}{|c|}{ Interstation section } \\
\hline & $\begin{array}{c}\text { Interlocking } \\
\text { system }\end{array}$ & $\begin{array}{l}\text { Number of } \\
\text { main track }\end{array}$ & $\begin{array}{l}\text { Coefficient of } \\
\text { free capacity of } \\
\text { main track }\end{array}$ & Heterogeneity & $\begin{array}{l}\text { Spatiality } \\
\text { coefficeint }\end{array}$ \\
\hline \multicolumn{6}{|l|}{ ŽST Humenné } \\
\hline Humenné - Strážske & 0,49 & 1 & 0,27 & 2 & 0,03 \\
\hline \multicolumn{6}{|l|}{ ŽST Strážske } \\
\hline Strážske - Petrovce n. Laborcom & 0,67 & 1 & 0,57 & 2 & 0,04 \\
\hline \multicolumn{6}{|l|}{ Výh. Petrovce n. Laborcom } \\
\hline Petrovce n. Laborcom - Michalovce & 0,67 & 1 & 0,57 & 2 & 0,07 \\
\hline \multicolumn{6}{|l|}{ ŽST Michalovce } \\
\hline Michalovce - Bánovce n. Ondavou & 0,67 & 1 & 0,57 & 2 & 0,04 \\
\hline \multicolumn{6}{|l|}{ ŽST Bánovce n. Ondavou } \\
\hline Bánovce n. Ondavou - Hrinište & 0,67 & 1 & 0,57 & 2 & 0,07 \\
\hline \multicolumn{6}{|l|}{ Výh. Hrinište } \\
\hline Hrinište - Trebišov & 0,67 & 1 & 0,57 & 2 & 0,07 \\
\hline \multicolumn{6}{|l|}{ ŽST Trebišov } \\
\hline Trebišov - Čel'ovce & 0,67 & 1 & 0,67 & 2 & 0,06 \\
\hline \multicolumn{6}{|l|}{ Výh. Čel'ovce } \\
\hline Čel'ovce - Výh. Slivník & 0,67 & 1 & 0,67 & 2 & 0,06 \\
\hline \multicolumn{6}{|l|}{ Výh. Slivník } \\
\hline Výh. Slivník - Slanec & 0,78 & 2 & 0,58 & 2 & 0,19 \\
\hline \multicolumn{6}{|l|}{ ŽST Slanec } \\
\hline Slanec - Ruskov & 0,78 & 2 & 0,58 & 2 & 0,23 \\
\hline \multicolumn{6}{|l|}{ ŽST Ruskov } \\
\hline Ruskov - Nižná Mšl'a & 0,78 & 2 & 0,58 & 2 & 0,23 \\
\hline \multicolumn{6}{|l|}{ ŽST Nižná Myšl'a } \\
\hline $\begin{array}{l}\text { Nižná Myšl’a - Krásna n. } \\
\text { Hornádom }\end{array}$ & 0,78 & 2 & 0,58 & 2 & 0,23 \\
\hline \multicolumn{6}{|l|}{ ŽST Krásna n. Hornádom } \\
\hline Krásna n. Hornádom - Košice & 0,78 & 2 & 0,58 & 2 & 0,17 \\
\hline ŽST Košice & & & & & \\
\hline
\end{tabular}

Table 6. Allocation of weights by factors of transport point of the Humenné - Košice transport route

\begin{tabular}{|c|c|c|c|c|c|c|c|}
\hline \multirow[b]{2}{*}{$\begin{array}{l}\text { Name of operating } \\
\text { control point/open line }\end{array}$} & \multicolumn{7}{|c|}{ Transport point } \\
\hline & $\begin{array}{c}\text { Interlocking } \\
\text { system }\end{array}$ & $\begin{array}{l}\text { Stoppi } \\
\text { ng } \\
\text { time of } \\
\text { a train }\end{array}$ & $\begin{array}{l}\text { Number of } \\
\text { edges of } \\
\text { platform }\end{array}$ & $\begin{array}{l}\text { Coefficient } \\
\text { of free } \\
\text { capacity of } \\
\text { the station } \\
\text { gridiron }{ }^{1}\end{array}$ & $\begin{array}{l}\text { Coefficient } \\
\text { of free } \\
\text { capacity of } \\
\text { running } \\
\text { track }\end{array}$ & $\begin{array}{l}\text { Number of } \\
\text { connecting } \\
\text { railway }\end{array}$ & $\begin{array}{c}\text { Numb } \\
\text { er of } \\
\text { runnin } \\
\text { g track }\end{array}$ \\
\hline ŽST Humenné & \multicolumn{7}{|c|}{ ORIGINATING STATION } \\
\hline \multicolumn{8}{|l|}{ Humenné - Strážske } \\
\hline ŽST Strážske & 0,51 & 0,95 & 3 & 0,30 & 0,51 & -1 & 8 \\
\hline \multicolumn{8}{|l|}{$\begin{array}{c}\text { Strážske - Petrovce n. } \\
\text { Laborcom }\end{array}$} \\
\hline $\begin{array}{l}\text { Výh. Petrovce n. } \\
\text { Laborcom }\end{array}$ & 0,51 & 0 & 0 & $\mathbf{0 , 3 0}$ & 0,51 & 0 & 2 \\
\hline \multicolumn{8}{|l|}{$\begin{array}{c}\text { Petrovce n. Laborcom - } \\
\text { Michalovce }\end{array}$} \\
\hline ŽST Michalovce & 0,56 & 0,92 & 2 & 0,30 & 0,51 & 0 & 5 \\
\hline $\begin{array}{c}\text { Michalovce - Bánovce n. } \\
\text { Ondavou }\end{array}$ & & & & & & & \\
\hline
\end{tabular}

\footnotetext{
${ }^{1}$ In the column of free capacity of the station gridiron and main tracks, the blue numbers represent only the model value of the capacity, as the infrastructure manager does not have the exact data of these transport points at all.
} 
Table 6. continued

\begin{tabular}{|c|c|c|c|c|c|c|c|}
\hline $\begin{array}{c}\text { ŽST Bánovce n. } \\
\text { Ondavou }\end{array}$ & 0,60 & 1,58 & 3 & $\mathbf{0 , 3 0}$ & 0,51 & 0 & 5 \\
\hline \multicolumn{8}{|l|}{$\begin{array}{c}\text { Bánovce n. Ondavou - } \\
\text { Hrinište }\end{array}$} \\
\hline Výh. Hrinište & 0,60 & 0 & 0 & 0,30 & 0,51 & 0 & 2 \\
\hline \multicolumn{8}{|l|}{ Hrinište - Trebišov } \\
\hline ŽST Trebišov & 0,56 & 1,50 & 5 & 0,30 & 0,51 & -1 & 6 \\
\hline \multicolumn{8}{|l|}{ Trebišov - Čel'ovce } \\
\hline Výh. Čel’ovce & 0,60 & 0,50 & 2 & 0,30 & 0,51 & 0 & 2 \\
\hline \multicolumn{8}{|l|}{ Čel'ovce - Výh. Slivník } \\
\hline Výh. Slivník & 0,60 & 0 & 0 & 0,30 & 0,51 & -1 & 3 \\
\hline \multicolumn{8}{|l|}{ Výh. Slivník - Slanec } \\
\hline ŽST Slanec & 0,60 & 1,00 & 3 & 0,75 & 0,91 & 0 & 5 \\
\hline \multicolumn{8}{|l|}{ Slanec - Ruskov } \\
\hline ŽST Ruskov & 0,60 & 1,50 & 4 & 0,75 & 0,91 & 0 & 5 \\
\hline \multicolumn{8}{|l|}{ Ruskov - Nižná Mšl’a } \\
\hline ŽST Nižná Myšl’a & 0,60 & 1,00 & 3 & 0,75 & 0,91 & 0 & 4 \\
\hline \multicolumn{8}{|l|}{$\begin{array}{c}\text { Nižná Myšl’a - Krásna } \\
\text { n. Hornádom }\end{array}$} \\
\hline $\begin{array}{c}\text { ŽST Krásna n. } \\
\text { Hornádom }\end{array}$ & 0,60 & 1,00 & 3 & 0,75 & 0,91 & -1 & 6 \\
\hline \multicolumn{8}{|l|}{$\begin{array}{c}\text { Krásna n. Hornádom - } \\
\text { Košice }\end{array}$} \\
\hline ŽST Košice & & & $\mathrm{TE}$ & $\overline{\text { STAT }}$ & & & \\
\hline
\end{tabular}

Table 7. The sum of the assigned weights of the line section factors in the even direction

\begin{tabular}{|c|c|c|c|c|c|}
\hline \multirow[b]{2}{*}{$\begin{array}{l}\text { Name of operating control point/open } \\
\text { line }\end{array}$} & \multicolumn{5}{|c|}{ Interstation section } \\
\hline & $\begin{array}{c}\text { Interlocking } \\
\text { system }\end{array}$ & $\begin{array}{l}\text { Number of } \\
\text { main track }\end{array}$ & $\begin{array}{l}\text { Coefficient of } \\
\text { free capacity of } \\
\text { main track }\end{array}$ & Heterogeneity & $\begin{array}{l}\text { Spatiality } \\
\text { coefficient }\end{array}$ \\
\hline \multicolumn{6}{|l|}{ ŽST Humenné } \\
\hline Humenné - Strážske & \multicolumn{5}{|c|}{3,79} \\
\hline \multicolumn{6}{|l|}{ ŽST Strážske } \\
\hline Strážske - Petrovce n. Laborcom & \multicolumn{5}{|c|}{4,28} \\
\hline Výh. Petrovce n. Laborcom & \multicolumn{5}{|c|}{ 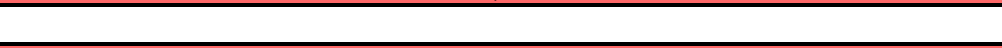 } \\
\hline Petrovce n. Laborcom - Michalovce & \multicolumn{5}{|c|}{4,31} \\
\hline ŽST Michalovce & & & & & \\
\hline Michalovce - Bánovce n. Ondavou & \multicolumn{5}{|c|}{4,28} \\
\hline ŽST Bánovce n. Ondavou & \\
\hline Bánovce n. Ondavou - Hrinište & \multicolumn{5}{|c|}{4,31} \\
\hline Výh. Hrinišste & \\
\hline Hrinište - Trebišov & \multicolumn{5}{|c|}{4,31} \\
\hline ŽST Trebišov & & & & & \\
\hline Trebišov - Čel'ovce & \multicolumn{5}{|c|}{4,40} \\
\hline Výh. Čel'ovce & & & & & \\
\hline Čel’ovce - Výh. Slivník & \multicolumn{5}{|c|}{4,40} \\
\hline Výh. Slivník & \\
\hline Výh. Slivník - Slanec & \multicolumn{5}{|c|}{5,55} \\
\hline ŽST Slanec & & & & & \\
\hline Slanec - Ruskov & \multicolumn{5}{|c|}{5,59} \\
\hline ŽST Ruskov & & & & & \\
\hline Ruskov - Nižná Mšl’a & \multicolumn{5}{|c|}{5,59} \\
\hline ŽST Nižná Myšl’a & \multicolumn{5}{|c|}{ 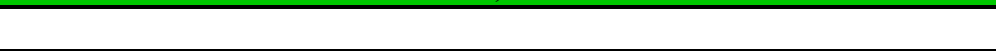 } \\
\hline Nižná Myšl’a - Krásna n. Hornádom & \multicolumn{5}{|c|}{5,59} \\
\hline ŽST Krásna n. Hornádom & \multicolumn{5}{|c|}{ בצ,כ, } \\
\hline Krásna n. Hornádom - Košice & \multicolumn{5}{|c|}{5,53} \\
\hline $\begin{array}{c}\text { ŽST Košice } \\
\end{array}$ & \\
\hline
\end{tabular}


Table 8. The sum of the assigned weights of the transport point factors in the even direction

\begin{tabular}{|c|c|c|c|c|c|c|c|}
\hline \multirow[b]{2}{*}{$\begin{array}{c}\text { Name of operating control } \\
\text { point/open line }\end{array}$} & \multicolumn{7}{|c|}{ Transport point } \\
\hline & $\begin{array}{l}\text { Interlocking } \\
\text { system }\end{array}$ & $\begin{array}{c}\text { Stopping } \\
\text { time of a } \\
\text { train }\end{array}$ & $\begin{array}{l}\text { Number } \\
\text { of edges of } \\
\text { platform }\end{array}$ & $\begin{array}{c}\text { Coefficient of } \\
\text { free capacity } \\
\text { of the station } \\
\text { gridiron }\end{array}$ & $\begin{array}{c}\text { Coefficient of } \\
\text { free capacity } \\
\text { of running } \\
\text { track }\end{array}$ & \begin{tabular}{|c|}
$\begin{array}{c}\text { Number } \\
\text { of } \\
\text { connecting } \\
\text { railway }\end{array}$ \\
\end{tabular} & $\begin{array}{c}\text { Number } \\
\text { of } \\
\text { running } \\
\text { track }\end{array}$ \\
\hline ŽST Humenné & \multicolumn{7}{|c|}{ ORIGINATING STATION } \\
\hline \multicolumn{8}{|l|}{ Humenné - Strážske } \\
\hline ŽST Strážske & \multicolumn{7}{|c|}{12,27} \\
\hline \multicolumn{8}{|l|}{$\begin{array}{c}\text { Strážske - Petrovce n. } \\
\text { Laborcom }\end{array}$} \\
\hline $\begin{array}{l}\text { Výh. Petrovce n. } \\
\text { Laborcom }\end{array}$ & \multicolumn{7}{|c|}{ TURN-OUT } \\
\hline \multicolumn{8}{|l|}{$\begin{array}{l}\text { Petrovce n. Laborcom - } \\
\text { Michalovce }\end{array}$} \\
\hline ŽST Michalovce & \multicolumn{7}{|c|}{9,29} \\
\hline \multicolumn{8}{|l|}{$\begin{array}{c}\text { Michalovce - Bánovce n. } \\
\text { Ondavou }\end{array}$} \\
\hline ŽST Bánovce n. Ondavou & \multicolumn{7}{|c|}{10,99} \\
\hline \multicolumn{8}{|l|}{$\begin{array}{l}\text { Bánovce n. Ondavou - } \\
\text { Hrinište }\end{array}$} \\
\hline Výh. Hrinište & \multicolumn{7}{|c|}{ TURN-OUT } \\
\hline \multicolumn{8}{|l|}{ Hrinište - Trebišov } \\
\hline ŽST Trebišov & \multicolumn{7}{|c|}{12,87} \\
\hline \multicolumn{8}{|l|}{ Trebišov - Čel'ovce } \\
\hline Výh. Čel'ovce & \multicolumn{7}{|c|}{5,91} \\
\hline \multicolumn{8}{|l|}{ Čel’ovce - Výh. Slivník } \\
\hline Výh. Slivník & \multicolumn{7}{|c|}{ TURN-OUT } \\
\hline \multicolumn{8}{|l|}{ Výh. Slivník - Slanec } \\
\hline ŽST Slanec & \multicolumn{7}{|c|}{11,26} \\
\hline \multicolumn{8}{|l|}{ Slanec - Ruskov } \\
\hline ŽST Ruskov & \multicolumn{7}{|c|}{12,76} \\
\hline \multicolumn{8}{|l|}{ Ruskov - Nižná Mšl’a } \\
\hline ŽST Nižná Myšl’a & \multicolumn{7}{|c|}{10,26} \\
\hline \multicolumn{8}{|l|}{$\begin{array}{c}\text { Nižná Myšl’a - Krásna n. } \\
\text { Hornádom }\end{array}$} \\
\hline ŽST Krásna n. Hornádom & \multicolumn{7}{|c|}{11,26} \\
\hline \multicolumn{8}{|l|}{$\begin{array}{l}\text { Krásna n. Hornádom - } \\
\text { Košice }\end{array}$} \\
\hline ŽST Košice & \multicolumn{7}{|c|}{ TERMINAL STATION } \\
\hline
\end{tabular}

Table 9. Calculation table of the level of stability of the transport route in the even direction.

\begin{tabular}{|l|c|}
\hline Interstation section & 61,92 \\
\hline The total sum of the weights of the criteria & 13 \\
\hline Total number of zones & $\mathbf{4 , 7 6}$ \\
\hline Breakthrough value of zone determination & 8 \\
\hline Condensation zones & 5 \\
\hline Compensation zones & $\mathbf{0 , 3 8}$ \\
\hline Stability level & \\
\hline Transport point & 96,87 \\
\hline The total sum of the weights of the criteria & 12 \\
\hline Total number of zones & $\mathbf{1 0 , 7 6}$ \\
\hline Breakthrough value of zone determination & 3 \\
\hline Condensation zones & \\
\hline
\end{tabular}


Table 9. continued

\begin{tabular}{|l|c|}
\hline Compensation zones & 9 \\
\hline Stability level & $\mathbf{0 , 7 5}$ \\
\hline Stability level transport route & $\mathbf{0 , 5 7}$ \\
\hline
\end{tabular}

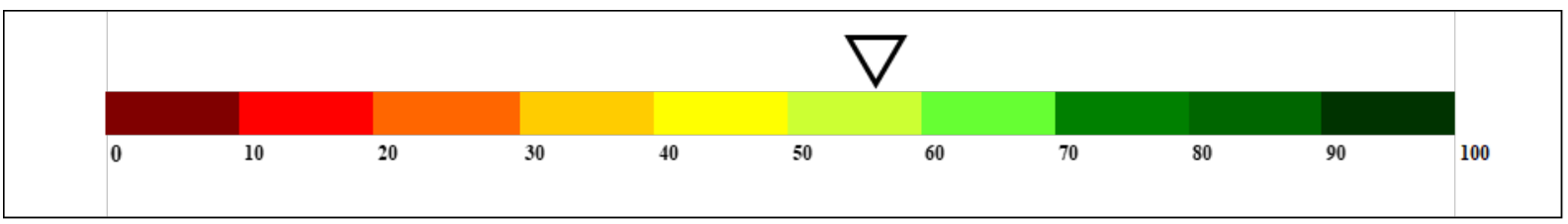

Fig. 2. Graphic expression of the stability of the Humenné - Košice transport route for an even direction

\section{Conclusion}

The proposed methodology examines the ability to reduce delays, which it considers as one of the main components of tact timetables stability and looks at the issues addressed in terms of operational and infrastructure factors. In this way, it seeks to contribute to the optimization and improvement of railway transport in the tasks of public passenger transport. The methodology consists of partial steps of a heuristic procedure, which consistently identify and characterize the factors influencing the stability of tact timetables. It will gain importance in the field of tact timetable as well as integrated transport system, where it helps to compile such complex timetables more efficiently and thus can serve as an aid or guide for the infrastructure manager in the creation of various technological or construction and reconstruction measures.

Further research in this area may lead to the quantification of other elements of infrastructure or elements of operation, which need to be determined for a more detailed perception of this methodology and thus reveal a broader view showing the entanglement of interconnections in connection with determining the level of stability or reliability of timetables. However, it is important to set these relevant criteria correctly and subsequently to effectively apply the proposals, which can lead to a more rational design of train traffic diagram and thus lead to reliable railway operation to attract and retain customers and thus increase demand and quality of rail transport.

\section{References}

ANDERSSON, E. V., et al., Quantifying railway timetable robustness in critical points, Journal of Rail Transport Planning and Management, Volume 3, Issue 3, s. 95-110. 2013, http://dx.doi.org/10.1016/j.jrtpm.2013.12.002

CACCHIANI, V., TOTH, P., Nominal and robust train timetabling problems, European Journal of Operational Research, Volume 219, Issue 3, 2012 , s. 727-737, ISSN 0377-2217, https://doi.org/10.1016/j.ejor.2011.11.003.
CAIMI, G., et al., Design of a Railway Scheduling Model for Dense Services, Netw Spat Econ 9, 2009, s. 25-46, https://doi.org/10.1007/s11067008-9091-6

LÜTHI, M., The Train Departure Process and its Impact on the Rail Network Performance, 7thSwiss Transport Research Conference, 2007, s. 20, Dostupné na internete: http://www.strc.ch/2007/2007_johner.pdf

MENG, X., LIMIN, J., WANLI, X., Complex network model for railway timetable stability optimisation, IET Intelligent Transport Systems, Volume 12, Issue 10, 2018, s. 1369 - 1377, https://doi.org/10.1049/iet-its.2018.5257

Decree UIC 406, Capacity, France, Paris, 2013 